\title{
Contralateral sandwich myocutaneous anterolateral thigh flap for salvage of femoral artery repair in an infected groin wound: an innovative technique
}

\author{
Ravikiran Naalla 두, Ashish Dhanraj Bichpuriya, Maneesh Jain, Maneesh Singhal
}

Plastic Reconstructive \& Burns Surgery, All India Institute of Medical Sciences, New Delhi, India

\section{Correspondence to} Professor Maneesh Singhal; drmaneesh@gmail.com

Accepted 19 January 2020

\section{DESCRIPTION}

A 45-year-old man was referred to us for the management of an infected groin wound following femoral artery repair. One week earlier he sustained fall from a rooftop and was diagnosed with pelvic diastasis, right acetabular fracture, femoral artery and vein injury. He underwent femoral artery repair with $10 \mathrm{~cm}$ interposition great saphenous vein graft, ligation femoral vein and non-operative management for pelvic diastasis. On examination of the right groin, we noticed a $20 \times 5 \mathrm{~cm}$ wound covered with slough and purulent discharge. There was persistent lymphorrhoea from the wound and the patient's serum albumin was $1.4 \mathrm{~g} / \mathrm{dL}$. As there is a

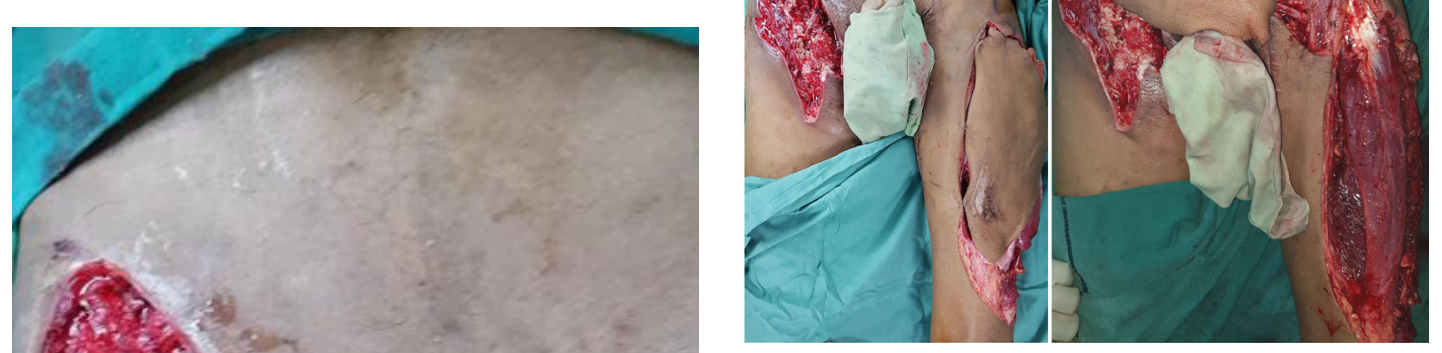

Figure 1 Image showing $(A)$ right groin wound status before debridement, (B) after debridement (exposed vein graft can be seen over the forceps). (C) Left myocutaneous anterolateral thigh flap after harvest. (D) Transposition of the flap across the suprapubic region on to the right groin.

risk of graft failure/blow out of the vascular repair, a plan for an urgent wound exploration and flap cover was made.

Intraoperatively the infected blood clots were washed off, gangrenous thigh muscles were debrided. The reverse saphenous vein graft was found to be patent. The size of the wound after debridement was $25 \times 12 \mathrm{~cm}$ with exposed vein graft $(7 \mathrm{~cm})$ (video 1). As the deep femoral vessels were ligated earlier, ipsilateral thigh flaps were unavailable. Hence, contralateral myocutaneous anterolateral thigh (ALT) flap $(35 \times 12 \mathrm{~cm})$ was harvested and tunnelled under the rectus femoris (RF) and sartorius across the suprapubic region (in the subcutaneous plane) to reach the right thigh (figure 1). By this submuscular transposition, an additional $5 \mathrm{~cm}$ length of the flap pedicle was gained. Because of dead space, infected and ischaemic thigh muscles surrounding the vein graft the vastus lateralis $(\mathrm{VL})$ muscle component of the flap 


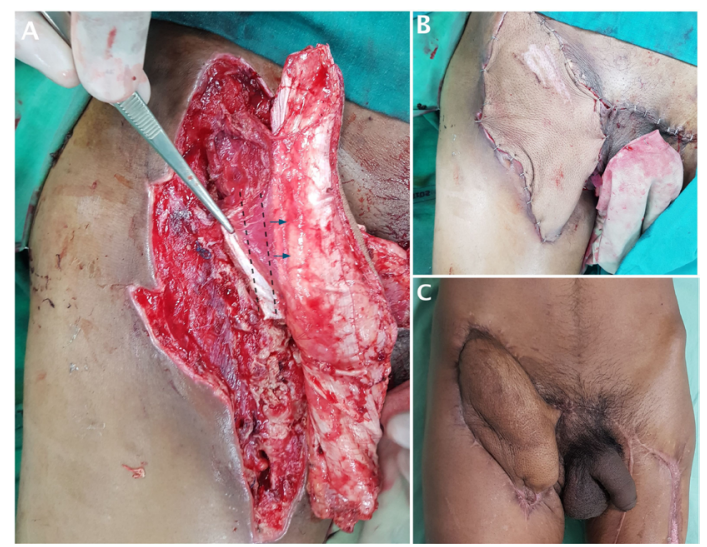

Figure 2 (A) Right groin wound with transposed contralateral myocutaneous anterolateral thigh (ALT) flap. The vastus lateralis (VL) muscle was used to sandwich the vein graft (indicated by dotted lines). Lateral margin of VL muscle was held with the forceps over the anterior surface of the vein graft and the medial margin (invisible) was passed under the vein graft to cover the vein graft circumferentially. The arrows indicate the location of the myocutaneous perforator of the ALT flap. (B) After flap inset. (C) Well settled flap.

was passed around the vein graft and sutured to exclude the vein graft from the infected wound bed. To achieve this the VL muscle had to be debulked before folding on itself around the vein graft. The folded muscle was supported with a couple of 3-0 vicryl sutures.

\section{Patient's perspective}

I'm happy to be able to stand on my both legs and walk again.
Postoperatively, the RF muscle was gangrenous due to stretch in the perforator supplying it. Retrospectively, we feel that division of the perforators to the RF muscle and discarding the RF muscle would have been an acceptable procedure. This manoeuvre increases the reach of the flap especially in our circumstance, where the wound was large and oriented longitudinally in contrary to the authors who have preserved the RF muscle. ${ }^{12}$ There was mild suture line dehiscence at the flap site and it was covered with a skin graft. Lymphorrhoea was managed conservatively and subsided after 3 weeks (figure 2). The patient had mild weakness in the terminal extension of the left knee (due to loss of RF muscle) which improved with physiotherapy.

Conventionally, large groin wounds are covered with sartorius muscle flap, gracilis myocutaneous flap, tensor fascia lata flap, RF flap and rectus abdominis flap. ${ }^{3}$ In our patient, the femoral artery and its branches were not available. Contralateral rectus abdominis flap was not an ideal option as there was significant dead space and large soft tissue defect. The free flap was not the first option as there was a paucity of the recipient vessels and there was a risk of total flap loss in an already critical patient. The contralateral ALT flap was the best option as it provided abundant soft tissue to obliterate the dead space and skin resurfacing simultaneously. Although the contralateral ALT procedure was reported earlier ${ }^{12}$ sandwiching the artery in the VL muscle has not been reported. We believe that this technique not only protects the vascular repair in an infected groin wound, but also obliterates the dead space and provides soft tissue cover for early wound healing.

Contributors RN is the operating surgeon and involved in patient care and manuscript preparation. MJ is involved in data collection and patient care. ADB is involved in patient care. MS is the professor incharge and approval of the drafted manuscript.

Funding The authors have not declared a specific grant for this research from any funding agency in the public, commercial or not-for-profit sectors.

Competing interests None declared.

Patient consent for publication Obtained.

Provenance and peer review Not commissioned; externally peer reviewed.

ORCID iD

Ravikiran Naalla http://orcid.org/0000-0001-7658-1073

\section{REFERENCES}

1 Hulika N, Naru RR, et al. Contralateral pedicled anterolateral thigh flap (ATL) for upper thigh defect in the era of free ATL? World J Plast Surg 2016;5:194-7.

2 Bharath SP, Madhusudan G, Manjunath S. Pedicled anterolateral thigh flap for contralateral groin composite defect. Indian J Plast Surg 2010;43:103-5.

3 Sörelius K, Schiraldi L, Giordano S, et al. Reconstructive surgery of inguinal defects: a systematic literature review of surgical etiology and reconstructive technique. In Vivo 2019;33:1-9.

Copyright 2020 BMJ Publishing Group. All rights reserved. For permission to reuse any of this content visit

https://www.bmj.com/company/products-services/rights-and-licensing/permissions/

BMJ Case Report Fellows may re-use this article for personal use and teaching without any further permission.

Become a Fellow of BMJ Case Reports today and you can:

- Submit as many cases as you like

- Enjoy fast sympathetic peer review and rapid publication of accepted articles

- Access all the published articles

- Re-use any of the published material for personal use and teaching without further permission

Customer Service

If you have any further queries about your subscription, please contact our customer services team on +44 (0) 2071111105 or via email at support@bmj.com.

Visit casereports.bmj.com for more articles like this and to become a Fellow 